\title{
Miranda
}

Revue pluridisciplinaire du monde anglophone /

Multidisciplinary peer-reviewed journal on the English-

speaking world

$20 \mid 2020$

Staging American Nights

\section{Vincent Dussol and Adriana şerban (eds.). Poésie- traduction-cinéma / Poetry-translation-film}

\section{Will Noonan}

\section{OpenEdition}

\section{Journals}

Electronic version

URL: http://journals.openedition.org/miranda/23339

DOI: 10.4000/miranda.23339

ISSN: 2108-6559

\section{Publisher}

Université Toulouse - Jean Jaurès

\section{Electronic reference}

Will Noonan, "Vincent Dussol and Adriana Şerban (eds.). Poésie-traduction-cinéma / Poetry-translationfilm ", Miranda [Online], 20 | 2020, Online since 19 March 2020, connection on 16 February 2021. URL: http://journals.openedition.org/miranda/23339 ; DOl: https://doi.org/10.4000/miranda.23339

This text was automatically generated on 16 February 2021.

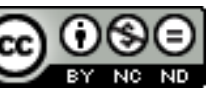

Miranda is licensed under a Creative Commons Attribution-NonCommercial-NoDerivatives 4.0 International License. 


\section{Vincent Dussol and Adriana şerban (eds.). Poésie-traduction-cinéma / Poetry-translation-film}

Will Noonan

\section{REFERENCES}

Vincent Dussol and Adriana şerban (eds.). Poésie-traduction-cinéma / Poetry-translationfilm. Limoges: Lambert-Lucas, 2018, 358 pages, 39 euros. 


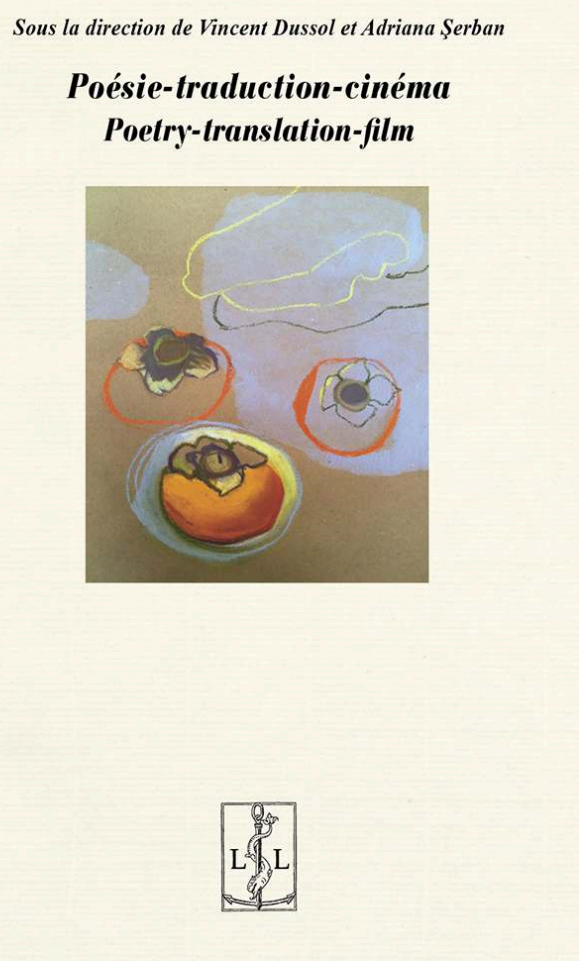

Introducing an essay on the problems of subtitling film adaptations of Shakespeare for French speaking audiences, editors Vincent Dussol and Adriana şerban invoke the metaphor of triangulation to describe "a network of relations between 'poetry', 'translation' and 'film"' (29) that lies at the heart of their collected volume. The metaphor is apt in that it refers not only to the intersection of the three subject terms but also to the navigational exercise of plotting course and location with respect to established coordinates. As the editors point out, the links between poetry and translation studies, translation and film studies and film and poetry studies are all well charted in academic literature, though the interrelationships between the three fields have not previously given rise to a book-length academic publication. Their volume is positioned as an attempt to explore this critical terrain, a task at which its necessarily eclectic collection of essays broadly succeeds.

Poésie-traduction-cinema / Poetry-translation-film has its roots in a conference organized by the EMMA research group at the University of Montpellier 3-Paul Valéry in June 2015. In its published form, it brings together fourteen essays of varying length, six in French and eight in English, along with Tom Konyves' "Videopoetry: A Manifesto" and "In Retrospect: A Manifesto and Its Underpinnings", Dussol's French translations of Konyves' texts into French, and a substantial introduction by the editors printed in both French and English. While the organization of the volume in three distinct sections ("Approches historiques", "Propositions théoriques" and "Pionniers, explorateurs et praticiens") offers a nod to its French origins, the bilingualism evident in the introduction, and in the doubled French and English texts of Konyves' work, offers in itself a kind of manifesto for critical exchange running across both languages and disciplines.

3 This promise is echoed in the essays that follow the introduction, with translations in and between English and French joined by examples in Anglo-Saxon, German, Polish, 
Russian, Spanish and American Sign Language and by a wide range of poetry, film and multimedia genres including but not limited to "film-poems" and other hybrid works defined by the crossing of boundaries. Some essays approach translation in the strict sense of interlingual transfer, others in the sense of intersemiotic transfer from medium or art form to another: the book's central theme lends itself to both these approaches and the individual essays, grounded by an introduction that discusses a useful cross-section of literary translation theory, mostly avoid the temptation to invoke "translation" as a purely metaphorical conceit. While the editors remark on the initial difficulty of compiling a bibliography to cover the book's three topic areas, the references supplied at the end of each essay offer a useful starting point for further reading. This is enhanced by the indices of proper names, works cited and concepts provided for the volume as a whole: ease of use is sometimes hampered by heterogeneous terminology and by the bilingual nature of the collection ("film poétique", "film poetry", "film-poem" and "film-poème" are recorded as separate entries that mostly refer to the same group of essays), but this is more than compensated by the opportunity afforded to explore the variety of ways in which concepts and references are used across the collection.

4 François Bovier's essay "La traduction verbo-iconique dans le cinéma d'avant-garde: de l'écriture "pictographique» de H. D. aux films "textuels» de Hollis Frampton" (49-72) opens the volume by tracing the link between the history of audiovisual translation, the "translations" from text to image-both poetic and cinematic-explored in 1920s avantgarde film theory and practice, and the inverse "translation" of image into text seen in works such as Hollis Frampton's Hapax Legomena (1972), in which the relationship between the image and the visual-verbal message it contains highlights the materiality both of language and of the film as a product. As Bovier concludes (69), both case studies illustrate the ways in which film is constructed through the prism of verbal language, as a "translation" aimed at the medium of the screen.

This perspective is echoed in Mathias Kusnierz' contribution "Montage rythmique et traduction intermédiale: Comment théoriser les transferts entre la poésie et le cinéma d'avantgarde américains ?" (73-98), which explores the role of prosody in avant-garde poetry and montage in avant-garde film as a process of "translation" between "reality and its representations of the indecipherable" "le réel et ses representations de l'indéchiffrable", 95) and the "readable" text. Drawing on theorists including Roman Jakobson, Kusnierz claims that interlingual, intersemiotic and intermedial translation imply a similar process of figuration and defiguration operating at different levels of language (96).

Originally published in 2011, Tom Konyves' "Videopoetry: a Manifesto" (99-111; 113-126 as "Vidéopoésie: un Manifeste") offers a counterpoint to these theoretical considerations, aiming to "distinguish videopoetry from poetry films, film poetry, poemvideos, poetry videos, cyber-poetry, cine-poetry, kinetic poetry, digital poetry, poetronica, filming of poetry and other unwieldy neoglogisms" (99) using criteria including text types, image, motion, poetic technique and experience, sound and voices. In contrast to Bovier's and Kusnierz' perspectives, Konyves' discussion of translation is restricted to the provision of text (whether audio or visual) in multiple languages following relatively standard subtitling procedures, and his explicit framing of the videopoem as a multilingual artform provides a welcome concrete perspective on how poetry, film and translation (proper) can interact within a complex creative multimedia product. The fact that Konyves' follow-up "In Retrospect: A Manifesto and Its Underpinnings" 
(127-133; 135-142 as "Dans le rétroviseur : les raciness d'un manifeste") does not directly consider issues of translation points, arguably, to the relatively uncontroversial status of multilingualism in art compared to the relationships between poetry, creation, film and image and between interlingual, intersemiotic and intermedial translation.

7 The problematic status of translation also forms the background to Marta Kaźmierczak's essay "From Poetry into Film-and Back (through Translation)" (145-168), which opens the book's second section, Propositions théoriques. Kaźmierczak reads the 1926 Polish modernist poem "Panna Anna" against Lilith, a 2012 German short film adaptation, and "Missy Trissy", a 2014 translation of the poem into English. The Exploring how a reading of the film and translated poem as, respectively, an interlingual translation and an intersemiotic transmutation is complicated by the coexistence of two modern texts that adapt the original poem's language and themes in markedly different ways, Kaźmierczak notes that, ironically, the film adaptation remains in most respects closer to the original text.

8 Far from being restricted to the movement from text to film, Jakobson's notion of intersemiotic translation also underlies Juha-Pekka Kilpiö's concept of kinekphrasis, or "the verbal representation of cinema", developed in the essay "Shot at a Remake: Bob Perelman's Kinekphrasis beyond Cinematic Poetry” (169-184). However, Kilpiö identifies kinekphrasis less as a form of transmediality, or adaptation from one medium to another, than as a type of media representation, in which the object "translated" is described verbally in a way that does not necessarily mimic cinematic devices but rather "casts doubt on the concrete image and foregrounds instead the conceptual potential of verbal language so as to elaborate and complicate the political connotations of the film" (183).

9 The other perspectives developed in the theoretical section of the volume focus, in different ways, on the relationship between poetry and film. In contrast to Kaźmierczak and Kilpiö's reflection on how to frame translation with respect to the relationship between poetry and film, Lambert Barthélémy's essay "Plume, stylet, colle : Le poème Brakhage" (185-198) begins with the question of how cinema-and, in this case, particularly Stan Brakhage's experimental cinema-can be conceptualised as a "translation" of one or more poetic dimensions. This line of questioning finds a curious echo in Philippe Marty's essay “Coupe-tourne-dure: Aise et movement avec Wenders, Reverdy, Tacite, Dickinson" (199-208), which explores the differing uses and possible convergences of terms and concepts across the fields of poetry, cinema and translation. For example, the French verb tourner ('turn') can refer to the process of writing ("turning" a text to give the desired result, to the shift from one line of verse to another (seen in English in the "turn" of a sonnet), to translation ("turning" from one language, and arguably from one form, to another) and to the act of creating a film ("camera rolling"). Rounding off the theoretical section, Hoi Lun Law's essay "The poetic point of view" (209-226) explores the ways in which film appropriates concepts from poetry. Framed in terms of Noël Burch's notion of how the plastic and semantic functions of a film coalesce into a poetic function, this analysis is mainly developed with respect to lyric poetry, offering the author a means to problematise the cinematic point of view.

The third and final section of the book, Pionniers, explorateurs et praticiens, is unsurprisingly the most heterogeneous, but also offers a useful illustration of the 
perspectives and practical applications to which a combined study of poetry, film and translation may lead. This is exemplified in Peter Cook, Kenny Lerner and Miriam Nathan Lerner's contribution "ASL Poetry: The body as film", which discusses how poetic performances in American Sign Language-exemplified by the film Charlie, made available on the publisher's website-constitute a form of "film language" making use of three-dimensional motion and placing the performer's body in the role of both camera and screen. This suggests many possible intersections with discussions of intermedial translation, though the authors are careful to note that "A translation is only required for the sake of hearing non-signers. When we 'write' a poem, it is created in sign language first" (233).

11 Nicolas Sanchez's essay “'You should live twice; in it and in my rhyme': Rime et rythme dans le sous-titrage des œuvres shakespeariennes” (237-252) analyses how rhythm, rhyme and meter are used to render verse forms and specific poetic effects in the French subtitles of filmed version of Shakespeare's plays in ways that combine established techniques for poetic translation with the strict time and space constraints imposed by subtitles while also playing on the viewer's relationship with the written, as well as the spoken, poetic word. As Zoë Skoulding argues in introduction to her essay "Caroline Bergvall's Drift: Subtitles and sounded text" (253-267), "The use of subtitles in a film may appear to situate the viewer straightforwardly between a known and an unfamiliar language, but it also occurs within a whole panoply of visual and audio techniques through which the audience is located in a represented space" (253).

Skoulding focuses on Caroline Bergvall's multimedia piece Drift, which combines images of contemporary migrants in the Mediterranean with subtitled and voiced-over translations of the Anglo-Saxon poem The Seafarer that force the viewer to "listen forensically to the relationship between sound, vision and language as they are used to investigate time and space in current political conditions" (266). The political and poetic ramifications of language and image are also evident in Eithne O'Neill's "'Is the Man Who Is Tall Happy?' The poetry of a documentary: Michael Gondry's animated portrait of Noam Chomsky" (269-286), which seeks to render its creator's interpretation of Chomsky's ideas in a production that plays on the relationship between photography and animation, past and present and on the two men's different native languages in a form that also recalls intertexts including Alexander Pope's 1734 Essay on Man.

The final three essays in the volume further illustrate the range of perspectives brought together by the intersection of poetry, film and translation. Loïc Millot's "Penser la traduction avec la tradition chrétienne : l'incarnation de la parole dans Le Miroir (1974) et Le Sacrifice (1986) d'Andreï Tarkovski" (287-308) discusses the Soviet director's use of poems written by his father to create images of childhood recalling the beheading of John the Baptist, while Cécile Marshall's "Supping with the Devil: Tony Harrison's Art of Translation and Film Poetry" (309-326) explores the relationships between the British poet and film director's use of "cultural amnesia" in the translation and updating of classic drama for contemporary social conditions and his later filmpoems. Bénédicte Chorier-Fryd's final short essay “'With the freedom of a second look': Ika / In and Out and Fanny Howe's Poetic Image" (327-336) examines Howe's video productions in the light of the more conventional poetry for which she is better known. In a manner echoing some other contributors to the volume, Chorier-Fryd frames the shift in medium from page to screen not as a shift between languages but as a "translation of ideas", concluding with a brief discussion of Walter Benjamin's "The 
Task of the Translator": "The 'second look' of the translation does follow the laws of fidelity to the original, while giving free rein to its own language. In its tangential course, the translation establishes but a fleeting contact with its origin, and it is infinitely free to continue its own path" (335).

An unreconstructed linguist might take issue with such a metaphorical application of translation theory and with others like it spread through the volume. However, this reading of Benjamin's text does highlight the interpretative possibilities of translation in a way that could also, arguably, be applied to broad definitions of both "poetry", extended back in time to the etymological root of poiesis as "making', and of "film", extended to encompass audiovisual and multimedia productions of all kinds. In this sense, the final contribution also highlights the volume's principal strength. More needs to be done to develop a coherent and systematic account of how poetry, translation and film and their associated critical apparatus might fit together, but Poésie-traduction-cinéma/Poetry-translation-film has opened up some intriguing new perspectives.

INDEX

Mots-clés: poésie, cinéma, traduction, intersémiotique, intermédialité

Keywords: poetry, film, translation, intersemiotic, intermediality

\section{AUTHORS}

\section{WILL NOONAN}

MCF études anglophones

Laboratoire TIL - Texte Image Langage

Université de Bourgogne Franche-Comté

will.noonan@u-bourgogne.fr 